\title{
The Cultural Diversity of German Companies' Executive Boards and the Success of Their Internationalisation
}

\author{
Sebastian Weusthoff ${ }^{1^{*}}$, Jana-Maria Grieser ${ }^{1}$ and Reinhard Meckl ${ }^{1}$ \\ ${ }^{1}$ University of Bayreuth, Universitätsstraße 30, D-95440 Bayreuth, Germany.
}

\begin{abstract}
Authors' contributions
This work was carried out in collaboration between all authors. Authors JMG and SW designed the study. Author JMG performed the statistical analysis, wrote the protocol, and wrote the first draft of the manuscript. Authors RM and SW managed the analyses of the study. Author SW managed structure, analysis, literature searches and argumentation of following drafts and the final version. The article benefited much from highly valuable reviews, comments and amendments by RM. All authors read and approved the final
\end{abstract} manuscript.

\section{ABSTRACT}

The sociocultural composition of executive boards has a long-term relevance for the success of their companies and their organisation's internationalisation. Companies must weigh the possible advantages of having employees from different cultural backgrounds against possible inefficiencies caused by cultural misunderstandings. Using on Upper Echelon theory and Social Capital theory we hypothesised that cultural diversity has a positive effect on internationalisation success. We used the "Blau Index" to calculate cultural diversity and measured internationalisation success as the level of internationalisation, a common success measure in internationalisation studies. Data were generated from companies' annual reports. SMT members' citizenships were additionally validated by internet-based business-oriented social networks. Controlling for team size and company size effects did not change our conclusions. Using a panel analysis, this article examines the effect of the level of cultural diversity in the boards of the DAX30 companies on their success in internationalising. Complementing previous studies, a slight but significant positive correlation was evident, assuming that a higher internationalisation success can be found in firms having a culturally diverse senior

\footnotetext{
*Corresponding author: Email: sebastian.weusthoff@uni-bayreuth.de;
} 
management team. Our study revealed a positive correlation between cultural diversity in SMTs and internationalisation success. The results of our study might serve as a good reason for adapting the social structures of German SMTs to the firms' economic reality. Furthermore, it may encourage the legislative body to reexamine the German Corporate Governance regulations from an international perspective. Future research could investigate this correlation on a broader basis and reinforce our argumentation, possibly by including cultural studies.

Keywords: Upper-Echelon theory; social capital; cultural diversity; internationalisation success; top management teams.

\section{INTRODUCTION}

In the last few years the proportion of different nationalities in the higher levels of German companies has risen. Simon Kucher \& Partners' eleven years long study of DAX companies' executive boards noted an increase from $13.3 \%$ in 2000 to $27.8 \%$ in 2011 (2011). This increase is not least because of the requirement for corporate governance boards to internationalise under the German Corporate Governance Codex (Regierungskommission Deutscher Corporate Governance Kodex, 2012, pp. Zif. No. 5.1.2 and 5.4.1) [1]. According to Hambrick and Mason's 'Upper Echelons' Theory (1984, cf. see also e. g. Hambrick, Cho, \& Chen, 1996 [2]; Athanassiou \& Nigh, 2002 [3]; Lee \& Park, 2006 [4]; Nielsen, 2010 [5]), characteristics of the senior management team have a decisive influence on the performance and success of a company. Studies of this perspective argue that the composition of the higher management levels strongly influences companies' ability to internationalise (Jans, 2004, p. 4 [6]; Stumpf, 2005 [7]; cf. Lee \& Park, 2006, p. 195 [4]; van Knippenberg \& Schippers, 2007, p. 518 [8]; Fernández-Ortiz \& Lombardo, 2009, p. 132 [9]; Nakui, Paulus, \& van der Zee, 2011, p. 2328 [10]).

This study aims to contribute to the as yet little researched correlation between cultural diversity and internationalisation success. Schmid and Dauth refer to a very restricted number of empirical studies which investigate the influence of the international diversity of the managing board on the level of internationalisation companies achieve $(\mathrm{N}=19)$ or on their commercial success ( $\mathrm{N}=9$ ) (cf. Schmid \& Dauth, 2012, pp. 780-781 [11]). They note that '...so far there has been little research into internationality of German boards and management teams' (cf. Schmid \& Dauth, 2012, p. 781 [11]). Only the studies by van Veen and Elbertsen (cf. 2008 [12]), Biemann and Wolf (cf. 2009 [13]) and Arnegger, Hofmann, Pull, and Vetter (cf. 2010 [14]) focus on German companies' executive boards (cf. Schmid \& Dauth, 2012, p. $781[11])$.

In order to answer the research question this study will examine the DAX30 companies over a period of 11 years using a panel analysis, which will research the correlation between the cultural composition of their senior management teams and the international performance of the firms. It will therefore enrich the current state of the research into the connection between cultural diversity and companies' success in internationalising. 


\section{THEORETICAL BASIS}

\subsection{Cultural diversity in Senior Management Teams}

The concept of the senior management team (SMT) first appeared in management literature at the start of the eighties and has since attracted increasing interest as a research topic (see also e.g. Bourgeois, 1980, p. 234 [15]; cf. Hambrick, 1994, p. 172 [16]). A SMT is comprised of a small group of managers who are at the top of the organisational hierarchy and therefore exerta significant influence on the company (cf. Hambrick \& Mason, 1984, p. 193 [17]; Pettigrew, 1992, p. 163 [18]; Finkelstein \& Hambrick, 1996, p. 8 [19]). In this study the executive boards take the function of SMTs, because in listed companies they serve as the responsible body for the strategic direction of the business. This study uses the terms "Top Management Teams" and "Senior Management Teams" interchangeably (see also e. g. Hambrick \& Mason, 1984, p. 201 [17]).

Cultural diversity has been defined in numerous ways from different perspectives (cf. Jackson, May, \& Whitney, 1995 [20]; Mannix \& Neale, 2005 [21]; Harrison \& Klein, 2007 [22]). The most widely known definition is that of Jackson et al. (cf. 1995, p. 217 [20]), which includes readily detectable characteristics, such as culture, age or gender, and underlying ones, such as values, attitudes, capabilities or education.

Within the framework of this study cultural diversity is defined as the heterogeneity of culture as well as national characteristics within a unit, i.e. within the SMTs (cf. Trice \& Beyer, 1993, pp. 82-83 [23]; Hofstede, 2001, pp. 11-12 [24]).

Opinions on the effects of the demographic composition of the SMT follow different strands of argument. On the one hand, diversity can be considered as a valuable resource (resource perspectives) but on the other, it can be seen as the source of conflict in the team process (process perspectives) (cf. Jans, 2004, p. 4 [6]).

Firstly, following the resource perspective, the cognitive theory states that demographic diversity is accompanied by cognitive diversity (cf. Cox, Lobel, \& McLeod, 1991, p. 829 [25]; Certo, Lester, Dalton, \& Dalton, 2006, p. 870 [26]), and therefore a culturally heterogeneous management team has a wide range of different experiences, capabilities and values at its command (cf. Jans, 2004, p. 4 [6]; van Knippenberg \& Schippers, 2007, p. 518 [8]). Secondly, according to the theory of social capital, a culturally diverse team has access to a broader range of information, thanks to the different social networks and contacts that the team members possess outside the company (cf. Adler \& Kwon, 2002 [27]; Certo et al., 2006 , p. 817 [26]). The array of perspectives, knowledge and information in culturally diverse SMTs leads to a better assessment of future events, more potential trade alternatives and a better knowledge of the likely consequences thereof (cf. Hambrick \& Mason, 1984, p. 195 [17]). This has a positive effect on the company's adaptability and flexibility in new competitive and problematic situations (cf. van Knippenberg \& Schippers, 2007, p. 518 [8]).

From the process perspective, diversity leads to a higher instance of conflict, less communication and little social integration (cf. Jans, 2004, p. 518 [6]). On the individual level this is caused by the natural affinity and ties which people with similar (cultural) characteristics share, and on the collective level by the effect of categorisation and identification processes with socially similar people (cf. Jans, 2004, p. 5 [6]). Theoretical explanations are provided by Tajeel and Turner's theory of social identity [28] as well as Byrne's similarity-attraction hypothesis [29]. People with comparable life experiences 
develop relatively similar attitudes, values and beliefs. Through these the interpersonal attractiveness of the interaction partner is reinforced (cf. Jans, 2004, p. 518 [6]; Mannix \& Neale, 2005, p. 39 [21]). Building on this, the theory of 'social identity' describes the way in which people differentiate between 'in-group' and 'out-group' people. The resultant fault lines (lines of tension) between the groups decrease their interpersonal attractiveness (cf. Thatcher, Jehn, \& Zanutto, 2003, p. 219 [30]; van Knippenberg \& Schippers, 2007, p. 518 [8]; Ruigrok, Mayr, \& Greve, 2010, pp. 7-8 [31]) and increase the risk of emotional conflict or less cooperation (cf. Ellwart, Mock, \& Rack, 2010, p. 17 [32]).

The organisation of the SMTs must identify and develop conditions in which the positive effects overcome the negative ones (cf. Ruigrok et al., 2010, pp.6-7 [31]), so that the benefits of cultural diversity can be used to their maximum potential. The survival and competitiveness of companies are dependent on their ability to successfully meet the challenge of internationalisation (cf. Gomez-Mejia \& Palich, 1997, p. 313 [33]; Sanders \& Carpenter, 1998, p. 158). The necessary collection of information and processing competence (cf. Sanders \& Carpenter, 1998, p. 158 [34]; Lee \& Park, 2006, p. 197 [4])can be supported by the cultural diversity within the management team. The team members' different experiences make a significant contribution to a better understanding and interpretation of the international environment (cf. Tacheva, 2007, p. 139 [35]), which optimises their interaction with it.

\subsection{The influence of SMTs on the Success of Internationalisation}

Many studies have considered possible methods for measuring how successfully companies have internationalised (e.g. Jaw \& Lin, 2009 [36]; Kaczmarek, 2009 [37]; Lu \& Beamish, 2004 [38]; (cf. e.g. Tallman \& Li, 1996 [39]; Lu \& Beamish, 2004 [38]; Jaw \& Lin, 2009 [36]; Kaczmarek, 2009 [38], for an overview cf. Schmid \& Dauth, 2012, pp. 774-777 [11]). It has been shown that internationalisation should bemeasured on the basis of multiple indicators, and that non-financial factors, e.g. geographical distribution, can also be useful.

Building on Cyert and March's 1963 'Behavioral Theory of the Firm' [40] (cf. Hambrick et al., 1996, p. 662 [2]; Nielsen, 2010, p. 303 [5]) and Hambrick and Mason's 1984 'Upper Echelons' theory [17], a group of people at the top of the company can be used as an object of analysis (cf. Carpenter, Geletkanycz, \& Sanders, 2004, pp. 752-753 [41]). The success of a company can be seen as a variable dependent on the strategic decisions of dominant groups - the top management - within the organisation (cf. Hambrick \& Mason, 1984, pp. 194-196 [17]), which is influenced by the traits and characteristics of the SMT members and their resultant heterogeneity (cf. Hambrick \& Mason, 1984, p. 193 [17]; Finkelstein \& Hambrick, 1990 [42]; Hambrick et al., 1996 [2]). Fig. 1 shows this presumed correlation.

Additionally, SMTs create social structures whose efficiency is likely to be influenced by existing social capital (cf. Adler \& Kwon, 2002 [27]; Shipilov \& Danis, 2006 [43]). Shipilov and Danis(2006)[43] state that social capital "is fundamental to understanding the [SMT] characteristics, strategic choice, environmental content and financial performance" (Shipilov \& Danis, 2006, p. 22 [43]). As internationalisation is an unpredictable field, it requires creative and sometimes unconventional decisions, which have to be synthesised and merged into a coherent strategy. Assuming that human capital factors influence social capital in SMTs (cf. Lin, 1999 [44]; Shipilov \& Danis, 2006 [43]), cultural diversity might also foster internationalisation success from a social capital angle by integrating its bridging and bonding potential (cf. Burt, 1992 [45]; Coleman, 1988 [46]; Granovetter, 1973 [47]). 
(I)

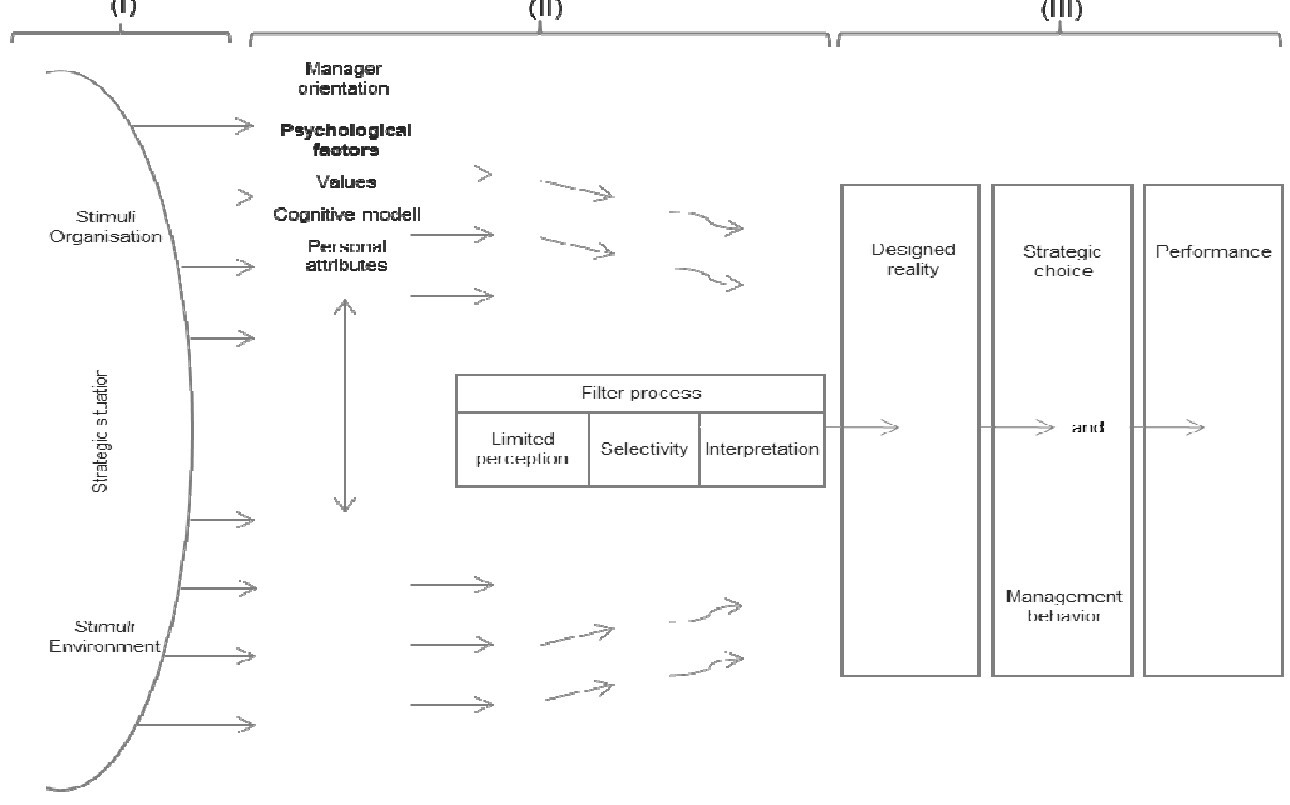

Fig. 1. Model of strategic choice in SMTs, taking bounded rationality into account Source: based on Finkelstein and Hambrick (1996, p. 42) [19]

Existing studies on the diversity of SMTs and their companies' performance portray a mixed picture. Positive (cf. e.g. Caligiuri, Lazarova, \& Zehetbauer, 2004 [48]; Boone \& Hendriks, 2009 [49]), negative (cf. Tsui, Egan, \& O'Reilly III, 1992 [50]) or no correlations (cf. Olson, Parayitam, \& Twigg, 2006 [51]), as well as simultaneous positive and negative connections (cf. Hambrick et al., 1996 [2]; Richard \& Shelor, 2002 [52]), can be identified. An explanation of this is the very different ways in which the topic has been approached and treated (cf. Harrison \& Klein, 2007, p. 1200 [22]; Fernández-Ortiz \& Lombardo, 2009, p. 134 [9]). The literature does not usually differentiate between the various different aspects of diversity (cf. Tacheva, 2007, p. 62 [35]), but treats it as a general construct. Every feature of diversity is assigned to the same effect, regardless of the disparity between them (cf. Hambrick \& Mason, 1984 [17]; Finkelstein \& Hambrick, 1996 [19]; Tacheva, 2007 [35]). Further causes of these dissimilar results could be the difference in the dependent variables, definitions used, and context factors considered (cf. Nielsen, 2010, p. 301 [5]; Nakui et al., 2011, p. 2328 [10]). Furthermore, there are studies with a decided focus on cultural diversity in SMTs (cf. Elron, 1997 [53]; Heijltjes, Olie, \& Glunk, 2003 [54]; Caligiuri et al., 2004 [48]), as well as those with thematically similar variables, such as international experience (cf. Athanassiou \& Nigh, 2002 [3]; Tacheva, 2007 [35]; Kaczmarek, 2009 [37]) which can be understood as synonymous with knowledge of 'foreign' countries and the understanding of values and backgrounds of practices and needs (cf. Athanassiou \& Nigh, 2002, p. 475 [3]; Kaczmarek, 2009, p. 176 [37]; Crisp \& Turner, 2011, p. 257 [55]). However, in the last ten years the discussion about the effect of cultural diversity in SMTs has widened from purely looking at companies' performance to other aspects of companies' diversity (cf. Herrmann \& Datta, 2005, p. 69 [56]; Tacheva, 2007, p. 137 [35]). 


\section{THE RESEARCH CONCEPT}

\subsection{Research Hypotheses}

Internationalisation leads to more complexity and as such to higher demands on the SMTs. Cultural diversity in the SMTs can therefore be conducive to dealing with complex factors in the most effective way.

Studies have shown that in the long term, negative operational effects caused by cultural diversity reduce the level of cooperation within an SMT. However, this study assumes that cultural diversity has a positive effect on information gathering and processing in SMTs, as SMTs usually work together for several years, so this negative influence has less of an effect on operations. Therefore a positive correlation between the diversity of SMTs and their companies' success in internationalising is anticipated.

The expression 'internationalisation success' is not explicitly used in management literature, but the nature of the aspects being researched makes it clear, that as a rule the degree of internationalisation is synonymous with its success. Drawing on Sullivan, 1994 [57], the degree of internationalisation is used as the factor for determining success. This leads to the following hypothesis:

Hypothesis 1: There is a positive correlation between cultural diversity in SMTs and the level of internationalisation attained by their companies.

Based on Sullivan, 1994 [57], a company's level of internationalisation can be divided into success-based, structure-based and behaviour-based dimensions. Relying on existing studies (cf. e.g. Lu \& Beamish, 2004 [38]; Jaw \& Lin, 2009 [36]) that build on Sullivan's work the behaviour-based dimension should be ignored. Doing so should not impair the research of the breadth (scale of the company's international diversification) or the depth (the significance of the overseas branches for the company), as the success-based dimension reflects the depth, and the structure-based dimension the breadth, of the internationalisation (cf. Jaw \& Lin, 2009, p. 226 [36]). As the proportion of foreign sales gives a success-based figure, and the number of foreign subsidiary companies offers a structure-based indicator, the following hypotheses can be reached:

Hypothesis 1a: There is a positive correlation between cultural diversity in SMTs and the proportion of a company's foreign country revenues.

Hypothesis 1b: There is a positive correlation between cultural diversity in SMTs and the proportion of a company's foreign country affiliates.

\subsection{Research Design}

\subsubsection{Sample}

The preliminary sample of the 30 DAX companies as of October 2011 was reduced to 28 after the removal of the banks taking financial crisis into account. German insurance groups remain included assuming that they did not suffer from financial crisis organisationally as banks. Therefore SMT composition of insurance groups is less influenced by externalities and can still be regarded as strategic choice. The companies included are all active internationally and function as limited companies with an executive board. Because the 
companies have different representative branches the results can be either be generalised or focused on a single branch (cf. Lee \& Park, 2006, p. 200 [4]). The data from the DAX 30 companies was compiled over a period of 11 years, from $2000-2010$. It was predominantly taken from the relevant reports from the companies, supplemented by their official websites as well as online databases (e.g. LexisNexis, Munziger Online, Wirtschafts Woche Online) when information was missing. Additionally, direct contact with the relevant employees was attained in some cases (Investor Relations). The final sample was reduced to 17 companies, because some lacked data. So overall this yielded a sample with $\mathrm{U}=17$ companies, with a research period of $\mathrm{T}=11$ and $\mathrm{N}=187$ observations.

\subsubsection{Putting the research into operation}

Level of internationalisation (LI): The level of internationalisation is usually analysed using multidimensional measurements, in order to boost its validity. This approach will be followed and the degree of internationalisation will be measured as the average of the proportion of a company's revenues coming from abroad and the quantity of foreign subsidiaries. The construct 'level of internationalisation' takes a value from 0 (no internationalisation) to 1 (a high level of internationalisation).

Proportion of foreign revenues (FR): the proportion of a company's foreign country revenues was measured by Sullivan, 1994 [57] as the ratio of foreign revenues in relation to a company's total revenue (cf. Sanders \& Carpenter, 1998 [34]; Lu \& Beamish, 2004 [38]; Lee \& Park, 2006 [4]; Jaw \& Lin, 2009 [36]). This variable can take a value between 0 (no foreign revenues) and 1 (where a company's total revenue all comes from abroad).

The proportion of foreign affiliates (FA): the measurement of the proportion of subsidiary companies which are foreign was also inspired by previous studies (see above) and is defined as the ratio of foreign subsidiary companies to the total number of subsidiary companies (Sullivan, 1994), taking a value between 0 (no foreign subsidiaries) and 1 (all subsidiaries abroad). Subsidiaries of the companies were only chosen if they were fully included in the consolidated balance sheet in the company's report, as per the German commercial code (§ 294, § 310) and the International Finance Reporting Standards (IAS 27).

Cultural diversity $(C D)$ in SMTs: cultural diversity refers to the composition of the executive board and is defined here in reference to the nationality of the board members. Citizenship passes here for a person's characteristics as well as morals (cf. Kaczmarek, 2009, p. 59 [37]) and ensures the accessibility of the data (cf. for more and broader coverage of Cultural Diversity in Senior Management Teams Schmid \& Dauth, 2012 [11]).

The extent of cultural diversity can be measured using different dispersion measurements (cf. Allison, 1978 [58]; Jans, 2004, p. 9 [6]; van Knippenberg \& Schippers, 2007, p. 522 [8]; Mayr, 2010, pp. 33-34 [59]). The Blau Index (BI) has been chosen for this study, as it is commonly used in diversity studies (cf. Kilduff, Angelmar, \& Mehra, 2000 [60]; Richard \& Shelor, 2002 [52]; Olson et al., 2006 [51]; Houghton, Stewart, \& Barr, 2010, p. 102 [61]; MacCurtain, Flood, Ramamoorthy, West, \& Dawson, 2010 [62]; Nielsen, 2010, p. 309 [5]). The $\mathrm{BI}$ considers the different behaviours associated with belonging to minorities or majorities within a team (cf. Mannix \& Neale, 2005, p. 37 [21]) and is calculated as:

$$
B I=1-\sum_{j=1}^{n}\left(a_{j}\right)^{2}
$$

$(0 \leq B I<1)$. 
The $\mathrm{BI}$ is therefore the representative number of the proportion of people belonging to a certain nationality within the group as a whole. The BI can theoretically take a value between 0 and 1 . The bigger the value is, the more diverse the group (the SMT) is with respect to the considered characteristic (Nationality).

Boards lasting less than a year were not included in the analysis. Following (Ruigrok et al., 2010), people with dual nationality were coded as 'half nationalities' using the respective nationality j, so that the proportion was shared between both nationalities.

\subsubsection{Control variables}

In this investigation the sizes of the management team and the company will act as the control variables. These have already been applied in many studies and have proved relevant (cf. e.g. Hambrick et al., 1996 [2]; Athanassiou \& Nigh, 2000 [63]; Tihany, Ellstrand, Daily, \& Dalton, 2000 [64]; Richard \& Shelor, 2002 [52]; Olson et al., 2006 [51]; FernándezOrtiz \& Lombardo, 2009 [9]).

\subsubsection{Team size}

The size of the SMT can influence the level of heterogeneity. Larger teams can consist of more members with different nationalities. In contrast, smaller teams can be more volatile, in that one additional member with a different nationality will have a greater influence on the group's makeup (cf. Tihany et al., 2000, p. 1169 [64]).

\subsubsection{Company size}

The size of the company can have an influence on its strategic initiatives. Larger companies have the personnel and the resources to enter the international market (cf. Tihany et al., 2000 , p. 1168 [64]). The size of the company will be measured by the amount of members in each respective year of the report (cf. e.g. see also Tihany et al., 2000 [64]; Fernández-Ortiz \& Lombardo, 2009 [9]).

\subsubsection{Statistical analysis}

There are observations for all 17 of the included companies and all the measurement points, so this studyis comprised of a balanced panel of 187 observations. A panel analysis offers noteworthy advantages (cf. Schröder, 2009, p. 315 [65]) as it offers a broader information base (cf. e.g. Tacheva, 2007, p. 82 [35]; Schröder, 2009, p. 315 [65]) compared to pure longitudinal data (cf. Tacheva, 2007, p. 82 [35]; Schröder, 2009, p. 315 [65]). Information about the chronological sequence of conditions and events can be obtained, which allows unobserved individual heterogeneity to be scrutinised (cf. Schröder, 2009, p. 315 [65]; Wooldridge, 2009, pp. 11-12 [66]).

Building on a simple model (the zero model), which provides basic conclusions about the data structure, a model with fixed effects (FE model) was applied to the relationship being investigated. The review of the assumptions of the linear mixed model used was accomplished using a linear regression (cf. Field, 2009, p. 739 [67]). 


\section{DATA INTERPRETATION AND RESULTS}

\subsection{Descriptive Statistics}

The average size of the companies was 151,635 employees, with a range from 9,645 to 520,112 . The average size of the SMTs (executive boards) was 6.89 members, with a variation between 4 and 14 members. The mean values, standard deviation, domain (Min./Max.) and the correlation of the different variables are shown in Table 1.

The SMTs had an average cultural diversity value of .205, with a range between .000 and .720. The high standard deviation of the cultural diversity value is particularly noteworthy, as it highlights a wide variation in the cultural composition of the executive boards $(M=.205$, $\mathrm{SD}=.199$ ). The correlations are positively biased, since the present panel data structure cannot be factored in the Pearson product-moment correlation. Likewise, significance cannot be used as a valid measure. The high values for the correlation between the level of internationalisation and the dependent variables are explained by the way the construct is formed.

The results of the Durbin-Watson statistics show the presence of positive auto-correlation $\left(\mathrm{DW}_{\mathrm{FR}}=.372 ; \mathrm{DW}_{\mathrm{FA}}=.300 ; \mathrm{DW}_{\mathrm{LI}}=.395\right)$. Auto-correlation is a well-known problem with panel data. Furthermore, the regression has considerable weaknesses with respect to the quality of the conformance. The proportion of the explained variance in relation to the total variance only accounts for $14 \%, 12 \%$ and $17 \%\left(r^{2} F_{R}=.144 ; r^{2}{ }_{F A}=.116 ; r^{2} L I=.171\right)$.

Table 1. Mean (M), standard deviation (SD), domain (Min./Max.) and product-moment correlation according to Pearson

\begin{tabular}{|c|c|c|c|c|c|c|}
\hline Variables & M SD & Min & Max & 1 & 2 & 3 \\
\hline 1. Cultural Diversity (CD) & .205 .199 & .000 & .720 & & & \\
\hline $\begin{array}{l}\text { 2. Share of foreign country revenues } \\
\text { (FR) }\end{array}$ & .653 .161 & .190 & .905 & $\begin{array}{l}.289^{* * *} \\
(.000)\end{array}$ & & \\
\hline $\begin{array}{l}\text { 3. Share of foreign country affiliates } \\
\text { (FA) }\end{array}$ & .728 .134 & .293 & .954 & $\begin{array}{l}.318^{\star * *} \\
(.000)\end{array}$ & $\begin{array}{l}.424^{* * *} \\
(.000)\end{array}$ & \\
\hline 4. Level of Internationalization (LI) & .690 .125 & .383 & .929 & $\begin{array}{l}.358^{\star \star \star} \\
(.000)\end{array}$ & $\begin{array}{l}.873^{* * *} \\
(.000)\end{array}$ & $\begin{array}{l}.811^{* * *} \\
(.000)\end{array}$ \\
\hline
\end{tabular}

The application of the linear mixed model (cf. Table 2) is corroborated by the high values of the calculated intraclass-correlation coefficients $\left(\mathrm{ICC}_{\mathrm{FR}}=.865 ; \quad \mathrm{ICC}_{\mathrm{FA}}=.866 ; \mathrm{ICC}_{\mathrm{LI}}=.858\right)$, which show that circa $86 \%$ of the total variance in each model can be traced back to the difference between the companies.

The total mean values (TMV) of the dependent variable show a relatively high average level of international activity across all the companies and measurement points. The average proportion of foreign revenues accounted for $65 \%$ of the total, the average amount of foreign subsidiary companies $73 \%$ and the level of internationalisation was, on average, $69 \%$ $\left(\mathrm{TMV}_{\mathrm{FR}}=.653 ; \mathrm{TMV}_{\mathrm{FA}}=.728 ; \mathrm{TMV}_{\mathrm{LI}}=690\right)$. Furthermore, it can be shown that a small but significant variation in the time series of each company is predominant $\left(\sigma_{\mathrm{WFR}}^{2}=.003, P<.001\right.$; $\left.\sigma_{\mathrm{WFA}}^{2}=.002, P<.001 ; \sigma_{\mathrm{W}}^{2}=.002, P<.001\right)$. Alongside this there are significant differences 
between each of the companies, which, compared to the variations in the companies' time series, are much more substantial $\left.\sigma_{\mathrm{BFR}}^{2}=.022, P=.01 ; \sigma_{\mathrm{BFA}}^{2}=.016, P=.01 ; \sigma_{\mathrm{BL}}^{2}=.013, P=.01\right)$.

Table 2. Zero model

\begin{tabular}{|c|c|c|c|}
\hline & FR & FA & LI \\
\hline Constant Term (total mean) & $\begin{array}{l}.653^{* * *} \\
(.037)\end{array}$ & $\begin{array}{l}.728^{\star \star \star} \\
(.030)\end{array}$ & $\begin{array}{l}.690^{\star \star *} \\
(.028)\end{array}$ \\
\hline Within-Variance: $\sigma_{W}^{2}$ & $\begin{array}{l}.003^{\star * *} \\
(.000)\end{array}$ & $\begin{array}{l}.002^{* * *} \\
(.000)\end{array}$ & $\begin{array}{l}.002^{* * *} \\
(.000)\end{array}$ \\
\hline Between-Variance: $\sigma_{B}^{2}$ & $\begin{array}{l}.022^{* *} \\
(.008)\end{array}$ & $\begin{array}{l}.016^{* *} \\
(.005)\end{array}$ & $\begin{array}{l}.013^{* *} \\
(.005)\end{array}$ \\
\hline Total Variance: $\sigma_{\text {total }}^{2}$ & .026 & .018 & .016 \\
\hline $\begin{array}{l}\text { Intraclass-correlation coefficient (ICC): } \\
I C C=\frac{\sigma_{B}^{2}}{\left(\sigma_{R}^{2}+\sigma_{W V}^{2}\right)}, 0 \leq I C C \leq 1\end{array}$ & .865 & .866 & .858 \\
\hline$-2 \mathrm{LL}^{+}\left(\mathrm{O}_{R} \mathrm{~T} / \mathrm{W/}\right.$ & -454.743 & -524.913 & $\begin{array}{l}- \\
54164\end{array}$ \\
\hline $\mathrm{AlC}^{+}$ & $-448,743$ & $-518,913$ & 535,64 \\
\hline
\end{tabular}

\subsection{Examination of the Hyopotheses}

The FE models (cf. Table 3) show significant positive correlations between cultural diversity and the proportion of a company's revenues coming from abroad, as well as the amount of subsidiary companies based abroad $\left(\mathrm{CD}_{\mathrm{FR}} \mathrm{FE}=.031, P=.10 ; \quad \mathrm{CD}_{\mathrm{FA}}-\mathrm{FE}=.037, P=.10\right)$. However, the strength of the correlation is not especially pronounced. Assuming the effects are fixed, hypotheses $1 \mathrm{a}$ and $1 \mathrm{~b}$ can be confirmed by a minor positive correlation. The empirical results are reflected in the assumed positive correlation between cultural diversity and the construct 'the level of internationalisation of companies' of hypothesis $1\left(\mathrm{CD}_{\mathrm{LI}}{ }^{-}\right.$ $\mathrm{FE}=.036, P=.05$ ). Only a slight correlation is shown here, but in comparison to previous studies it is clearly more substantial. Hypothesis 1 can therefore also be supported, assuming the effects are fixed. The substantially more significant correlation and the decided increase in the quality of the conformance compared to the first two models (proportion of foreign revenues and amount of foreign subsidiaries) confirm the observation into the construct (level of internationalisation) which has been carried out $\left(-2 L_{L}=-814.453\right.$ compared to $-2 L_{F R}=-747.652$ and $\left.-2 L_{F A}=-719.440\right)$.

The significance and the size of the correlation between cultural diversity and the amount of foreign subsidiaries stand out in comparison to that of the proportion of foreign revenues. In turn, the information criteria only have a low conformance, while neither of the two models may be given a preference regarding the results. The results for the control variables are particularly notable. None of the models show a noteworthy correlation between the management team or company size with their respective dependent variables. The disparate significance of the control variable stands out, but it is not within the scope of this study to investigate which reasons lie behind this. 
Table 3. Linear mixed model - FE model (fixed effects model)

\begin{tabular}{|c|c|c|c|c|c|c|}
\hline & \multicolumn{2}{|c|}{ FR } & \multicolumn{2}{|c|}{ FA } & \multicolumn{2}{|c|}{ LI } \\
\hline & Model 1 & Model 2 & Model 1 & Model 2 & Model 1 & Model 2 \\
\hline Team size & $-.002(.002)$ & $-.003^{\dagger}(.002)$ & $.001(.002)$ & $.000(.002)$ & $-.001(.001)$ & $-.001(.001)$ \\
\hline Company size & $.000^{* *}(.000)$ & $.000 *(.000)$ & $.000(.000)$ & $.000(.000)$ & $.000(.000)$ & $.000(.000)$ \\
\hline Cultural diversity & & $.031^{\dagger}(.019)$ & & $.037^{\dagger}(.021)$ & & $.036^{*}(.016)$ \\
\hline $\begin{array}{l}\text { Measurement } \\
\text { iterations } \\
\text { (ARH1 rho) }\end{array}$ & $.991^{\star * *}(.004)$ & $.990^{\star \star \star}(.005)$ & $.978^{\star \star *}(.008)$ & $.977^{\star \star \star}(.009)$ & $.985^{\star \star \star}(.007)$ & $.984^{\star * *}(.007)$ \\
\hline$-2 L L$ & -744.955 & -747.652 & -716.452 & -719.440 & -809.905 & -814.453 \\
\hline AIC & $-714,955$ & $-715,652$ & $-686,452$ & $-687,440$ & $-779,905$ & $-782,453$ \\
\hline
\end{tabular}

The analysis of the FE model confirms the positive correlation between cultural diversity and the level of internationalisation, the proportion of a company's revenue coming from abroad and the amount of subsidiary companies which are foreign, as posited in hypotheses 1, 1a and $1 \mathrm{~b}$. Following on from that, the positive connection between cultural diversity and success in internationalising can be supported by empirical evidence.

When comparing FE models and models with random effects (RE models), it was found that they only differ slightly from each other in terms of the quality of their conformance. The RE models show a trend towards a better conformance, but this confirms the conjecture that in comparison to the FE models the estimators are slightly distorted.

The results of the FE and RE models show similar behaviour with respect to the proportion of foreign revenues and the amount of foreign subsidiary companies, but not in terms of the level of internationalisation. In reference to hypotheses $1 \mathrm{a}$ and $1 \mathrm{~b}$ both models come to the same conclusion. With the RE model no conclusion could be reached for hypothesis 1 , but the simplified model (FE model) confirmed the hypothesis.

\section{DISCUSSION AND IMPLICATIONS}

In the descriptive statistics the low mean value (.205) and the high standard deviation stand out. In comparison, previous studies showed higher average values for cultural diversity (e.g. Tacheva, 2007 [35] with .34 or Kilduff et al., 2000 [61] with an average of .37 cultural diversity). A reason for this is the data this study was based on. Companies who displayed little or no cultural diversity over the observation period were wholly included in the analysis. With a relatively small sample and a comparatively long observation period this would have a significant effect on the mean value. In total 73 of the 187 observation values showed a cultural diversity of zero, meaning that with $39 \%$ of the observation points the boards showed no diversity.

With the linear mixed models the small sample and the lower level of diversity could also be reasons for the low strength of the correlation between cultural diversity and the dependent variables. In previous studies the correlation between cultural diversity and the dependent variables was found to be stronger. Elron, 1997 [53] established a correlation value of .18 and Caligiuri et al. 2004 [48] even found values from .30 to .49. Both studies had bigger samples and used American companies as the basis for their data. Furthermore, they both conducted cross-sectional analyses, while a panel analysis was used in this study. It is 
obvious that the influence of the sample size, the different companies and countries examined and the differing analysis methods were the reasons for the difference here.

With respect to proving the hypotheses the empirical results show a significant correlation between cultural diversity and the proportion of a company's revenues coming from abroad, as well as with the amount of subsidiary companies based abroad.

Foreign subsidiary companies represent the highest level of market integration but also the highest level of risk in foreign countries (cf. Meckl, 2010, pp. 16-17 [68]). A company with international subsidiary companies is therefore better established on the international market than a company with trade-based internationalisation (cf. Meissner \& Gerber, 1980, p. 224 [69]; Kutschker \& Schmid, 2011, p. 907 [70]). The experience and knowledge about 'foreign' markets (cf. Hambrick \& Mason, 1984, p. 195 [17]; van Knippenberg \& Schippers, 2007, p. 518 [8]), which a culturally diverse team possesses, can increase a company's readiness to take risks or invest. Consequently there is a stronger correlation between cultural diversity and the proportion of foreign subsidiary companies than between cultural diversity and the proportion of revenues coming from abroad.

The correlation between cultural diversity and the construct 'the level of internationalisation' can also be confirmed. The correlation is comparably strong, though it is clearly stronger than in the one dimensional models.

In this study, the investigated causality is based on the 'Upper-Echelons' Theory including the perspective of social capital. However, in reality the direction of the correlation between cultural diversity and success in internationalising must remain open to debate. Are culturally diverse SMTs responsible for the international alignment and success of their companies or does increasing internationalisation lead to a company having a culturally diverse SMT (cf. Tacheva, 2007, p. 142 [35])? Studies which examined the influence of internationalisation success on cultural diversity, rather than the other way round, also found this correlation (cf. Kaczmarek, 2009 [37]). In this case reference to the selection process for the SMTs was made. Therefore it would have to be considered, whether certain board members were chosen because they had a different nationality or whether their nationality was a coincidental result of choosing the best person for the job (cf. Tacheva, 2007, p. 68 [35]). As a rule nationality is not the only criterion used to make a decision, meaning that the best person for a job is not solely defined by their nationality. It would consequently make sense to examine further aspects of diversity both in isolation and as a whole construct, as well as integrating other relevant elements (e.g. CV, international experience, etc.), into future studies on this topic. To this end, the measurement of internationalisation recommended by Schmid and Dauth could be a useful point of departure for further research (cf. Schmid \& Dauth, 2012, p. 785 [11]).

In this study only one deciding aspect of cultural diversity was researched, as nationality was the only 'proxy variable' (cf. Tacheva, 2007, p. 140 [35]). In other studies several variables were examined. Generally, they were investigated in relation to the demographic characteristics of SMT members (cf. Herrmann \& Datta, 2005 [56]; Marimuthu \& Kolandaisamy, 2009 [71]; Ruigrok et al., 2010 [31]) and were often analysed as a construct rather than in isolation (cf. Hambrick \& Mason, 1984 [17]; Finkelstein \& Hambrick, 1996 [19]; Tacheva, 2007 [35]). As a counter to any criticism of the partial analysis carried out in this study, it can be argued that every demographic characteristic can have a different effect and as such must be researched separately (vgl. Mayr, 2010, p. 39 [59]). 
It can be questioned whether the demographic variable 'nationality' is a suitable proxy variable for the psychological characteristics and the behaviour of SMT members (cf. Edmondson, Roberto, \& Watkins, 2003, p. 4 [72]; Lee \& Park, 2006, p. 196 [4]; Schmid \& Dauth, 2012, p. 773 [11]), as people's values, beliefs and behaviour can strongly differ within a national group (cf. Kilduff et al., 2000, p. 22 [60]). Although this criticism seems partly valid, nationality has proved itself as a classic variable of intercultural management research, as due to its observability and implicit relationship with cultural variables it has often shown a sufficient approximation of the researched correlation.

In considering an overall evaluation of the correlation, the fact that SMTs are influenced by numerous internal and external factors must also be mentioned (cf. Bültel, 2009, p. 91[73]). Internal capacities and goals are not the only factors which play a role; external circumstances, for example the overall financial position or the market demand, also do so in equal measure. These internal and external influences have an effect both on the SMTs' decisions as well as the performance of a company. Variables often used in this research field, such as the size of the management team or company, were therefore integrated into this study.

Management team members do not make purely rational decisions, but are additionally constrained in their decision-making by the interactive tensions between the team members. A team member's perceptions of and attitudes to diversity or mutual trust can change the way they interact with their colleagues (cf. Tacheva, 2007, p. 141 [35]; van Knippenberg \& Schippers, 2007, p. 531 [8]; Nakui et al. 2011, p. 2328 [10]). Based on "cultural stereotypes, strategies of exclusion, and feelings of superiority" (cf. Zweigenhaft \& Domhoff, 2006 , p. 234 [74]) the formation of different groups is common, due to this perception as well as identification with colleagues who are similar. There is a widely established body of research concerning status attainment (cf. Loy, 1969 [75]; Smith \& Abbott, 1983 [76]), which might derogate a optimal resource allocation process and reduce the potential of social capital at the workplace. Within a team there are so-called faultlines (cf. Thatcher et al., 2003 [30]) which have a negative impact on teamwork. Such internal processes within the SMTs and between their individual members could be a possible explanation for the small correlation found in this study (cf. Bezrukova, Jehn, Zanutto, \& Thatcher, 2009, p. 35 [77]).

Considering that "firms with higher degrees of coalignment among their [SMT] social capital composition, strategic profile and external environment will enjoy superior performance" (Shipilov \& Danis, 2006, p. 22 [43]), firms therefore face the challenge of integrating cultural diversity into an approach of strategically managing diversity issues. As our study reveals, reflecting the business internationalisation in the SMTs' cultural structure might have a positive effect on firm performance. Likewise, Zweigenhaft and Domhoff (2006) [74] show an incease in (ethnic) diversity in American Fortune 1000 companies over the past two decades (cf. Zweigenhaft \& Domhoff, 2006, pp. 109-110 [74]). Therefore German firms would be well advised to strengthen their still weak overall cultural diversity in SMTs. For this purpose, Thomas(2010) provides a comprehensive framework which emphasises that "Organizations that desire the benefits of the behavioural variations that flow from demographic diversity would be wise not to eliminate or even minimize their associated representation tension" (Thomas, 2010, p. 56 [78]). Unfortunately the actual German Corporate Governance Codex does not actively promote cultural diversity in SMTs. The legislative body could may therefore consider adapting regulations to the culturally diverse reality of companies which are targeted by the Codex. However, assuming the challenges and imponderability of an increase in cultural diversity, managers might "see diversity as a problem to be solved and pushed aside" (Thomas, 2010, p.xii [78]). Focusing on the verified positive correlation 
between cultural diversity and internationalisation success the legislative body might be able to encourage German companies to comply with these possible new regulations.

\section{CONCLUSION}

The assumed positive correlation (based on Hambrick and Mason's 'Upper-Echelon' theory, 1984 [17]) between cultural diversity and the level of internationalisation, the proportion of revenues from abroad and the amount of subsidiary companies abroad was researched using 17 DAX companies and a data collection over a period of 11 years, and was evaluated using linear mixed models.

The empirical results confirmed the suggested hypotheses, as a small correlation was found in this study, as in other studies. However, it remains to be seen whether the small correlation can be attributed to a weak effect of cultural diversity in German companies or whether the small size of the sample, the different data basis or the statistical methods of analysis applied had an effect on the strength of the correlation.

In consideration of further research efforts into this thematic area a larger sample size could be used. In addition the focus could be directed towards certain sectors, so any possible differences can be identified. Further studies could analyse the opposite direction of the correlation researched here or investigate non-linear correlations.

The numerous studies about SMTs and their influence on the success of a company show the special position of the theme. However, an optimal arrangement of the SMTs using demographic variables would be difficult. On the one hand the internal processes are not known well enough; on the other there are many different influences on the level and success of internationalisation in internal and external company environments. Nevertheless this study showed that the cultural diversity of an SMT has a positive effect on the success of a company's internationalisation. It can therefore be used as a point of departure for further conceptual and methodical research into both diversity and senior management teams.

\section{ACKNOWLEDGEMENTS}

The authors acknowledge the valuable assistance of Mirjam Aberle and Cathy Lear in proofreading and adapting the article to the publishing company's guidelines.

The article benefited from highly valuable insights of NSFC Project-No.: 71272060/G0204

\section{COMPETING INTERESTS}

Authors have declared that no competing interests exist.

\section{REFERENCES}

1. Regierungskommission Deutscher Corporate Governance Kodex. Deutscher Corporate Governance Kodex (as amended on May 12 ${ }^{\text {th }}, 2012$ ). Frankfurt/Main. German; 2012. 
2. Hambrick DC, Cho TS, Chen MJ. The Influence of Top Management Team Heterogeneity on Firms' Competitive Moves. Adm Sci Q. 1996;41(4):659-84. DOI: $10.2307 / 2393871$.

3. Athanassiou N, Nigh D. The Impact of the Top Management Team's International Business Experience on the Firm's Internationalization: Social Networks at Work. MIR. 2002;42(2):157-81. Accessed 19 January 2014.

Available:http://search.ebscohost.com/login.aspx?direct=true \&db=buh\&AN=12150010 \&site=ehost-live.

4. Lee HU, Park JH. Top Team Diversity, Internationalization and the Mediating Effect of International Alliances. Br J Manag. 2006;17(3):195-213.

5. Nielsen S. Top Management Team Diversity: A Review of Theories and Methodologies. Int J Manag Rev. 2010;12(3):301-16.

6. Jans M. Empirical effects of demographic diversity in organizations organization. Results and findings of a meta-analysis. University of Duisburg-Essen. Essen; 2004. (Essener Beiträge zur Personalforschung, 3). German. Accessed 14 December 2012. Available: http://www.uni-due.de/personal/EBPF3.pdf.

7. Stumpf S. Synergie in multikulturellen Arbeitsgruppen. In: Stahl GK, Mayrhofer W, Kühlmann T, editors. International Human Resource Management: new challenges, new solutions. München [etc.]: Hampp German. 2005:115-44.

8. van Knippenberg D, Schippers MC. Work group diversity. Annu Rev Psychol. $2007 ; 58(1): 515-41$.

9. Fernández-Ortiz R, Lombardo GF. Influence of the capacities of top management on the internationalization of SMEs. Enterpren Reg Dev. 2009;21(2):131-54.

10. Nakui T, Paulus PB, van der Zee KI. The Role of Attitudes in Reactions Toward Diversity in Workgroups. J Appl Soc Psychol. 2011,41(10):2327-51. DOI: 10.1111/j.1559-1816.2011.00818.x.

11. Schmid S, Dauth T. International diversity in top management - An empirical analysis of the DAX-30 companies. zfbf. German. 2012;64(11):772-802.

12. Van Veen K, Elbertsen J. Governance Regimes and Nationality Diversity in Corporate Boards: A Comparative Study of Germany, the Netherlands and the United Kingdom. Corp Govern Int Rev. 2008;16(5):386-99. DOI: 10.1111/j.1467-8683.2008.00698.x.

13. Biemann $T$, Wolf $J$. Career patterns of top management team members in five countries: an optimal matching analysis. Int J Hum Resource Manag. 2009;20(5):97591. DOI: $10.1080 / 09585190902850190$.

14. Arnegger M, Hofmann C, Pull K, Vetter K. Differences in professional and demographic composition of German supervisory boards: an empirical survey for HDAX and SDAX companies. DBW German. 2010;70(3):239-57.

15. Bourgeois LJ. Performance and consensus. Strat Mgmt J. 1980;1(3):227-48.

DOI: $10.1002 / \mathrm{smj} .4250010304$.

16. Hambrick DC. Top Management Groups: A conceptual integration and reconsideration of the "team" label. Res Organ Behav.1994;16:171. Accessed 19 January 2014.

Available:http://search.ebscohost.com/login.aspx?direct=true\&db=buh\&AN=6815461\& site=ehost-live.

17. Hambrick DC, Mason PA. Upper Echelons: The Organization as a Reflection of Its Top Managers. Acad Manage Rev.1984;9(2):193-206. DOI: 10.2307/258434. 
18. Pettigrew AM. On studying managerial elites. Strat Mgmt J. 1992;13:163-82.

19. Finkelstein S, Hambrick DC. Strategic leadership. Top executives and their effects on organizations. Minneapolis/St. Paul: West Pub. Co; 1996.

20. Jackson SE, May KE, Whitney K. Understanding the dynamics of diversity in decisionmaking teams. In: Guzzo RA, Salas E, editors. Team effectiveness and decision making in organizations. 1st ed. San Francisco: Jossey-Bass. 1995:204-61.

21. Mannix E, Neale MA. What Differences Make a Difference? The Promise and Reality of Diverse Teams in Organizations. Psychol Sci. 2005;6(2):31-55.

22. Harrison DA, Klein KJ. What's the difference? Diversity constructs as separation, variety, or disparity in organizations. Acad Manage Rev. 2007;32(4):1199-228. DOI: 10.5465/AMR.2007.26586096.

23. Trice HM, Beyer JM. The cultures of work organizations. Englewood Cliffs, N.J: Prentice Hall; 1993.

24. Hofstede GH. Culture's consequences. Comparing values, behaviors, institutions, and organizations across nations. 2nd ed. Thousand Oaks, Calif: Sage Publications; 2001.

25. Cox, TH, Lobel SA, McLeod PL. Effects of ethnic group cultural differences on cooperative and competitive behavior on a group task. Acad Manage J. $1991 ; 34(4): 827-47$.

26. Certo ST, Lester RH, Dalton CM, Dalton DR. Top Management Teams, Strategy and Financial Performance: A Meta-Analytic Examination. J Manag Stud. 2006;43(4):81339.

27. Adler PS, Kwon SW. Social Capital: Prospects for a New Concept. Acad Manage Rev. 2002;27(1):17-40. DOI: 10.2307/4134367.

28. Tajfel H, Turner J. (1986): The social identiy theory of intergroup behavior. In: Austin WG, Worchel S, editors. Psychology of intergroup relations. 2nd ed. Chicago: NelsonHall Publishers. 1986;7-24.

29. Byrne DE. The attraction paradigm. New York: Academic Press; 1971.

30. Thatcher S, Jehn K, Zanutto E. Cracks in Diversity Research: The Effects of Diversity Faultlines on Conflict and Performance. Group Decis Negot. 2003;12(3):217-41.

31. Ruigrok W, Mayr R, Greve P. Understanding the differences: Top management team heterogeneity, firm performance, and the moderating role of age. Academy of Management. Montreal; 2010.

32. Ellwart T, Mock K, Rack O. Mixed-age cooperation. Potential for knowledge exchange, innovation and Development. Zürich: SPEKTRAmedia; 2010. German.

33. Gomez-Mejia LR, Palich LE. Cultural diversity and the performance of multinational firms. J Int Bus Stud.1997;28(2):309-35.

34. Sanders Gerard WM, Carpenter MA. Internationalization and firm governance: the roles of CEO compensation, top team composition, and board structure. Acad Manage J. 1998;41(2):158-78.

35. Tacheva S. Top management team diversity a multilevel exploration of antecedents and consequences. St. Gallen: Hochschule St. Gallen; 2007. Accessed 19 January 2014. Available: http://worldcatlibraries.org/wcpa/oclc/468983989.

36. Jaw YL, Lin WT. Corporate elite characteristics and firm's internationalization: CEOlevel and TMT-level roles. Int J Hum Resource Manag. 2009;20(1):220-33. 
37. Kaczmarek S. Nationality, international experience diversity and firm internationalisation: The implications for performance. St. Gallen; 2009.

38. Lu JW, Beamish PW. International diversification and firm performance: The s-curve hypothesis. Acad Manage J. 2004;47(4):598-609.

39. Tallman S, Li J. Effects of international diversity and product diversity on the performance of multinational firms. Acad Manage J. 1996;39(1):179-96.

40. Cyert RM, March JG. A behavioral theory of the firm. Englewood Cliffs N.J: PrenticeHall; 1963.

41. Carpenter MA, Geletkanycz MA, Sanders WG. Upper Echelons Research Revisited: Antecedents, Elements, and Consequences of Top Management Team Composition. J Manage 30. 2004;(6):749-78. DOI: 10.1016/j.jm.2004.06.001.

42. Finkelstein S, Hambrick DC. Top-Management-Team Tenure and Organizational Outcomes: The Moderating Role of Managerial Discretion. Adm Sci Q. 1990;35(3):484-503.

43. Shipilov A, Danis W. TMG Social Capital, Strategic Choice and Firm Performance. Eur Manag J. 2006;24(1):16-27. DOI: 10.1016/j.emj.2005.12.004.

44. Lin N. Social networks and status attainment. Annu Rev Sociol.1999;25(1):467. Accessed 20 February 2014.

Available:http://search.ebscohost.com/login.aspx?direct=true \&db=buh\&AN=2373058\& site $=$ ehost-live.

45. Burt RS. Structural holes. The social structure of competition. Cambridge, MA: Harvard University Press; 1992.

46. Coleman JS. Social Capital in the Creation of Human Capital. Am J Sociol. 1988;94:95. DOI: 10.2307/2780243.

47. Granovetter MS. The Strength of Weak Ties. Am J Sociol. 1973:78(6):1360-80. DOI: 10.2307/2776392.

48. Caligiuri $\mathrm{P}$, Lazarova $\mathrm{M}$, Zehetbauer $\mathrm{S}$. Top managers' national diversity and boundary spanning: Attitudinal indicators of a firm's internationalization. J Manag Dev. 2004;23(9):848-59. DOI: 10.1108/02621710410558459.

49. Boone C, Hendriks W. Top Management Team Diversity and Firm Performance: Moderators of Functional-Background and Locus-of-Control Diversity. Manage Sci. 2009;55(2):165-80.

50. Tsui AS, Egan TD, O'Reilly III CA. Being Different: Relational Demography and Organizational Attachment. Adm Sci Q. 1992;37(4):549-79.

51. Olson BJ, Parayitam S, Twigg NW. Mediating Role of Strategic Choice between Top Management Team Diversity and Firm Performance: Upper Echelons Theory Revisited. J Bus Manag. 2006;12(2):111-26.

52. Richard OC, Shelor RM. Linking top management team age heterogeneity to firm performance: juxtaposing two mid-range theories. Int $\mathrm{J}$ Hum Resource Manag. 2002;13(6):958-74.

53. Elron E. Top management teams within multinational corporations: Effects of cultural heterogeneity. Leadersh Q. 1997;8(4):393. Accessed 19 January 2014. Available: http://search.ebscohost.com/login.aspx?direct=true \&db=buh\&AN=66959\&site=ehostlive. 
54. Heijltjes $M$, Olie R, Glunk U. Internationalization of Top Management Teams in Europe. Eur Manag J. 2003;21(1):89-97. DOI: 10.1016/S0263-2373(02)00156-1.

55. Crisp RJ, Turner RN. Cognitive adaptation to the experience of social and cultural diversity. In: Psychol Bull. 2011;137(2):242-66. DOI: 10.1037/a0021840.

56. Herrmann P, Datta DK. Relationships between Top Management Team Characteristics and International Diversification: an Empirical Investigation*. $\mathrm{Br} \mathrm{J}$ Manag. 2005;16(1):69-78.

57. Sullivan D. Measuring the degree of internationalization of a firm. J Int Bus Stud.1994;25(2):325-42. Accessed 19 January 2014.

Available:http://search.ebscohost.com/login.aspx?direct=true\&db=buh\&AN=1906184\& site=ehost-live.

58. Allison PD. Measures of Inequality. Am Sociol Rev. 1978;43(6):865-80. DOI: 10.2307/2094626.

59. Mayr R. Top Management Team Age Structure and Firm Performance. St. Gallen; 2010.

60. Kilduff M, Angelmar R, Mehra A. Top Management-Team Diversity and Firm Performance: Examining the Role of Cognitions. Organ Sci. 2000;1(1):21-34.

61. Houghton SM, Stewart AC, Barr PS. Cognitive Complexity of the Top Management Team: The Impact of Team Differentiation and Integration Processes on Firm Performance. In: Rahim M, editor. Current Topics in Management: Organiational Behavior, Performance and Effectiveness. Transaction Publishers. 2010:95-115.

62. MacCurtain S, Flood PC, Ramamoorthy N, West MA, Dawson JF. The Top Management Team, Reflexivity, Knowledge Sharing and New Product Performance: A Study of the Irish Software Industry. Creativ Innovat Manag. 2010;19(3):219-32.

63. Athanassiou N, Nigh D. Internationalization, Tacit Knowledge and the Top Management Teams of MNCs. J Int Bus Stud. 2000;31(3):471. Accessed 19 January 2014.

Available:http://search.ebscohost.com/login.aspx?direct=true \&db=buh\&AN=3559803\& site=ehost-live.

64. Tihany L, Ellstrand AE, Daily CM, Dalton DR. Composition of the Top Management Team and Firm International Diversification. J Manage. 2000;26(6):1157.

65. Schröder A. Prinzipien der Panelanalyse. In: Albers S, Klapper D, Konradt U, Walter A, Wolf J, editors. Methodology of empirical research. 3rd ed. Wiesbaden: Gabler German. 2009;315-30.

66. Wooldridge JM. Introductory econometrics: a modern approach. 4th ed. Mason Ohio: South-Western Cengage Learning; 2009.

67. Field AP. Discovering statistics using SPSS. 3rd ed. Los Angeles, [Calif.], London: SAGE; 2009.

68. Meckl R. Internationales Management. 2nd ed. München: Vahlen German; 2010.

69. Meissner HG, Gerber S.

70. The foreign investment as a decision problem. BFuP. German. 1980;(3):217-28.

71. Kutschker M, Schmid S. Internationales Management. 7th ed. München: Oldenbourg German; 2011. 
72. Marimuthu M, Kolandaisamy I. Can demographic diversity in top management team contribute for greater financial performance? An empirical discussion. J Int Soc Res. 2009;8(8):273-86.

73. Edmondson AC, Roberto MA, Watkins MD. A dynamic model of top management team effectiveness: managing unstructured task streams. Leadersh Q. 2003;14(3):297-325.

74. Bültel S. Effectiveness of top management team: promoting open discussion on the board of German Corporations. Wiesbaden: Gabler German; 2009.

75. Zweigenhaft RL, Domhoff GW. Diversity in the power elite. How it happened, why it matters. Lanham, [Md]: Rowman \& Littlefield Pub; 2006.

76. Loy JW. The study of sport and social mobility: Problems, patterns and prospects. In: Kenyon GS, editor. Aspects of contemporary sport sociology. Proceedings. Chicago: Athletic Institute. 1969:101-19.

77. Smith DR, Abbott A. A Labor Market Perspective on the Mobility of College Football Coaches. Soc Forces. 1983;61(4):1147-67. DOI: 10.2307/2578284.

78. Bezrukova K, Jehn KA, Zanutto EL, Thatcher SMB. Do Workgroup Faultlines Help or Hurt? A Moderated Model of Faultlines, Team Identification, and Group Performance. Organ Sci. 2009;20(1):35-50. Accessed 19 January 2014.

Available:http://search.ebscohost.com/login.aspx?direct=true\&db=buh\&AN=36606900 \&site=ehost-live.

79. Thomas RR. World class diversity management. A strategic approach. 1st ed. San Francisco, [Calif]: Berrett-Koehler Publishers; ASAE \& The Center for Association Leadership (A BK business book); 2010.

(0) 2014 Weusthoff et al.; This is an Open Access article distributed under the terms of the Creative Commons Attribution License (http://creativecommons.org/licenses/by/3.0), which permits unrestricted use, distribution, and reproduction in any medium, provided the original work is properly cited.

\section{Peer-review history:}

The peer review history for this paper can be accessed here: http://www.sciencedomain.org/review-history.php?iid=427\&id=20\&aid=4012 